The final discussion of the confercnce was on school rnathematical societies. The main speakers were Mr. D. Hobbs (Exeter School) and Mr. A. R. Tammadge (Abingdon). Mr. Hobbs outlined tho activities of an ossentially practical society which thrived on the making of mathematical machines and models of all types, working computers being demonstrated. Mr. Tammadgo spoke of tho more culturally inclined senior society the modus vivendi of whick was based socially and intellectually on that of the university socioty.

\section{General Lectures}

Dr. J. F. Scott, deputizing for Prof. McKie, gave the Association a most absorbing account of the early history of tho Royal Socioty up to the early eighteenth century.

Prof. M. F. Atiyah, Savilian professor of geometry in the University of Oxford, spoaking on "Linear and NonLinear Mathematics", took mombers to some of tho frontiers of mathematics to-day, indicating the unity and simplicity of the subject. He showed the significance of linear methods in various parts of mathomatics and the advantages in translating certain kinds of non-linear problems into linear form: in this, one does not restrict oneself to finite dimensional linear problems but allows infinite dimensions.

Dr. K. Austwick, Department of Education, University of Sheffield, in an illustrated lecturo entitled "Automation in the Classroom", gave a balanced idea of the way in which tenching machines can bo used as an aid in the teaching of mathematics. The present machines, which are relatively unsophisticated, are mainly effective in tho teaching of motor skills and aro more useful for revision, remedial and self-tutoring work with studonts eapable of constructing responses. Conventional teaching cannot fail to benofit. In this respect his coneluding remark was very pertinent: "Any human teachor who can be replaced by a machine ought to be".

Mr. J. H. Durran (Winchester College), speaking under tho titlo "Do-it-yourself $\chi^{2 "}$, dolightfully demonstrated how the testing of goodness of fit in statistical work can $\mathrm{b} \theta$ approached in an intuitive and experienced way.

The final lecture and film of tho conference was "I Do and I Understand-a New Look at Primary School Mathematics", by Mr. J. W. G. Boucher, a former primary school toacher, and now a Fellow of the Nuffield Research Foundation. The attendance and interest shown by members at this final lecture showed that there is an incroasing awaroness among mathomaticians that, using as practical an approach as possiblo with young children, mathematics can become the favourite subject for all children.

\section{Elections and Future Conferences}

At the annual general meeting, Mrs. F. M. Williams was elected president for 1965-66. The following honorary officers wero re-olected. Treasurer, Mr. R. E. Green; Secretaries, Mr. F. W. Kellaway and Miss R. K. Tobias; Editor, Dr. E. A. Maxwell; Librarian, Prof. R. T. Goodstein; Assistant Secretaries, Mr. K. J. Backhouse, Instructor Captain R. G. Cross, Mr. B. J. F. Jorrington, Miss E. M. Holman, Dr. E. Kerr and Mr. C. Steele; Assistant T'reasutrer, Mr. N. Q. Dodds.

The 1966 meoting will bo hold in the University of North Staffordshire during April 13-16, 1966. The centenary meeting (1971) is being planned for University College, London, where the inaugural moeting of the Association for the Improvement of Geometrical Teaching (now the Mathematical Association) was held in 1871 .

R. G. Cross

\title{
SIXTY THOUSAND PERIODICALS
}

\begin{abstract}
$\mathrm{T}$ HE World List of Scientific Periodicals* was initiated late in 1920, when Sir Sidney F. Harmer, director of the Natural History departments of the British Museum, wrote to Sir Poter Chalmers Mitchell, secretary of the Zoological Society of London, asking him to direct the attention of the Conjoint Board of Scientific Studies to the problems of what is now referred to as information retrieval. The multiplicity of poriodicals, issued in various languages throughout the world, was alroady confusing. No single library held more than a fraction of the total number, and the Board was invited to consider the preparation of a list of scientific periodicals with an indication of the libraries where they were kept.

The Board adopted the suggestion, and work began late in 1921, under the guidance of the World List Association, incorporated as a limited company. The first edition concerned the years 1900-21; it was issued in two volumes of which the first, published in 1925, listed 24,128 titles, while the second volume, published in 1927, gave standard abbreviations and library locations. The second edition was issued in one volume in 1934 , and covered the years $1900-33$; the third edition, covering $1900-50$, was issued in 1952 and reprinted in 1958. The present edition covers the years $1900-60$ so that, like its prodocessors, it attempts to include every periodical which survived into the present century. About a quarter of the entries are titles published since 1950 and the total number is now more than 60,000 , and the List is now issued in three volumes. In spitc of the inconvenience in handling

* World List of Scientifle Periodicals Published in the Years 1900-1060 Edited by Peter Brown and George Burder Stratton. Vol. 1: A-F. Pp. $\mathrm{xxv}+1-532$. Vol. 2: $F-P$. $P^{2}, \mathrm{xx}+533-1186$. Vol. $3:$ : $Q-Z$ and Periodic International Congresses. Pp. 1187-1824. (London: Butterworths, 1963,
1964 and 19135.) 500s. per sct of three volumes.
\end{abstract}

which is inevitablo in a multi-volumo work of reference, this edition is even more genorally useful, and readily consulted, than its predecessors. A new type-face has beon omployed, words usod in the alphabetical arrangement are in bold type, and the numbor of cross-references has been increased. The transliteration of Cyrillic and Greok alphabots is in accordance with the recommendation of the Royal Socioty, modified and published as British Standard $2979: 1958$.

The abbroviation of titles of scientific periodicals according to a carefully considored systom, which has been a feature of the World List since its inception, has boon instrumental in effecting a degres of uniformity in bibliographic usage throughout the scientific world. The abbreviations in this edition follow a forthcoming British Standard, not greatly different from the system followed in previous editions.

This is to be the last edition of the World List compiled and produced in this way, by an Association which has no permanent staff and by editors whose main occupation is elsewhere. The first three editions wore prepared under the supervision of the late Mr. W. A. Smith, of the British Museum. After his death, before work on the fourth edition was begun, Mr. Peter Brown, also of the British Museum, undertook the editorship with Mr. G. B. Stratton, of the Zoological Society, who has beon associated with the World List from its earliest days. The Association has had four successive chairmen: Sir Peter Chalmers Mitchell, Dr. A. S. Noave, Dr. E. J. Holmyard, and the present chairman, Dr. L. Harrison Matthews. In future, it is proposed to continuo the List in the form of an annual cumulation of the material published quarterly by Bucop, the British Union Catalogue of 
Periodicals, published by the National Central Library. It is hoped that it will be possible to prepare 5- and 10-year compilations, offering to the user the convenience of the present compilation and incorporating the name World List in the title. Bucop employs a computerized system and the National Central Library commands resources commensurate with the immense amount of material which it will be necessary to handle.

The possibility of providing an index, to assist (for example) in tracing a periodical the title of which is incompletely known, is being borne in mind by the compilers of the computerized catalogue. It could hardly be expected within the framework of the World List as it is to-day. This edition is not absolutely free of errors, but it is clear that it has been most meticulously prepared. It is obviously impossible to guarantee the inclusion of every scientific periodical in a list compiled from information volunteøred by contributing libraries the stocks of which may not include every publication that could qualify. However, the number of libraries contributing to the present edition has been increased and, by courtesy of the Director, the compilers have had access to a number of titles held in the National Lending Library for Science and Technology, which was not officially opened until 1962.

Many new journals have been started since 1960, but nevertheless these three volumes provide an invaluable guide to all but a small fraction of the periodical literature a scientist may wish to consult, and to its whereabouts in British libraries.

\section{FIELD STUDIES COUNCIL}

1 CCORDING to the latest annual report of the Field A Studies Council*, the year 1963-64 saw a continuance of the growth in the number of students attending the Council's centres. The total number of student-weeks reached 11,617 (an increase of 12 per cent)--mainly as a result of edditional accommodation at Slapton Ley and of a full season at Orielton, but also because of larger bookings at other centres. This was divided between subjects as follows:

$\begin{array}{lr}\text { Biological subjects } & 5,979 \\ \text { Countryside and natural history } & 292 \\ \text { Geographical and geological } & 4,686 \\ \text { Art } & 245 \\ \text { Archaeology } & 219 \\ \text { Other courses } & 196\end{array}$

The number of individual attendances as distinct from the number of student weeks was 11,629, divided as follows:

$\begin{array}{lr}\text { Sixth forms } & 7,736 \\ \text { Other forms } & 192 \\ \text { Training colleges and teacher courses } & 1,569 \\ \text { Universities } & 1,160 \\ \text { Technical colleges } & \mathbf{1 4 5} \\ \text { Amateurs } & 827\end{array}$

Despite the extra numbers which the centres have been able to take, many hundreds of would-be students had to be turned away. It is the Council's aim and intention to open further centres when the necessary finance becomes available, and the New Centres Working Party is con-

- Field Studies Council. Annual Report, 1963-1964. IPp. 39+8 fphotographs. (London: Field Studies Council, 1965.) tinuing its search for suitable properties in areas where centres might be established. The Council was greatly heartened in the early part of the year to learn that the Worshipful Company of Drapers was proposing to make a grant of $£ 25,000$ to it to mark the occasion of the sexcentenary of the granting of the Company's first charter. Payment is to be made by instalments over a period of not more than five years; a condition of the grant is that it shall be used for purchasing and converting a property situated in North Wales to a field studies centre. Search immediately began for a suitable building. It was decided that the property most suitable to the Council's requirements was Rhyd-y-Creua, a house situated in the Conway Valley, one mile from Betws-yCoed. Rhyd-y-Creua is unlikely to be ready to accommodate students before the 1966 season commences.

Following the recommendation of the Scientific Advisory Committee, Preston Montford and Slapton Ley have bren inspected by the Department of Education and Science, the reports of which are now being awaited. Preston Montford was also visited by two scientists from the Sub-committee and as a result of their report and suggestions a new experimental biology course was in. augurated which, after one season, is considered to be very successful.

A small working party has been set up, the brief of which is to consider the educational aims and practice of the Field Studies Council in the light of present and future needs and to make recommendations to the Council.

\section{PHILOSOPHIES OF PIERRE TEILHARD DE CHARDIN}

\begin{abstract}
FIRST met Pierre Teilhard de Chardin as a young man, when we were assisting in prehistoric investigations in north Spain in 1912 or thereabouts. I also had occasion to see him from time to time until his death. $\mathrm{He}$ had a charming personality and was an excellent research worker in the fields of palaeontology and geology, and did much administrative work while living in China. He read deeply in the realm of philosophy, and was accepted wholeheartedly by others practising in that discipline. Above all, he was a profound Christian-a Roman Catholic and indeed a Jesuit. Not many men have reached the front rank in all these three disciplines, and therefore what he has to say is worthy of great consideration.
\end{abstract}

Teilhard was a firm believer in evolution-indeed, he was to some extent persecuted by his own hierarchy for this belief-but he did not confine evolution to living organisms; for him everything from the atom to reflective man has been influenced by evolution. He made no distinction between man and the animals, nor indeed between animate and inanimate objects. Matter had 'pre-life', an imperceptible particle of life, and was therefore also influenced by evolution. At present the effects of evolution tend to divergence, but in the case of reflective man must ultimately converge towards a unity which he called omega. For Teilhard this omega was equated with the incarnation, birth, life, death and resurrection of Jesus, the Christ.

Such a bald series of statements is, of course, grossly inadequate. It takes many hours of hard study properly to appreciate the width and depth of Teilhard's thought. It is a great pity that the older generation of Jesuits in 